\title{
Article
}

\section{Family social support and the self-esteem of breast cancer patients undergoing neoadjuvant chemotherapy}

\author{
Erik Aprilianto, Sih Ageng Lumadi, Feriana Ira Handian \\ Nursing Study Program, Maharani Health College, Malang, Indonesia
}

\begin{abstract}
Background: Neoadjuvant chemotherapy is the first step in breast cancer treatment. However, the medical procedure causes stressors on the self-concept of patients, especially low selfesteem, due to the decrease in the function of their limbs. This research aims to investigate the correlation between family social support and the self-esteem of breast cancer patients undergoing neoadjuvant chemotherapy. It was conducted using a cross-sectional approach.

Design and Methods: A sample of 56 people was selected by a simple random sampling technique, using a family social support questionnaire and the Rosenberg Self Esteem Scale.

Results: Based on the Spearman Rho statistical test, it was found that the $\mathrm{p}$-value was 0.000 with a correlation coefficient value of 0.762 . This indicated that there was a strong positive correlation between family social support and patient self-esteem.

Conclusions: Families are the closest systems to patients that play an important role as a coping strategy and in disease management. Therefore, it is suggested that family community groups should be developed among families that have breast cancer patients through social networking.
\end{abstract}

\section{Introduction}

Breast cancer is a malignant disease that most often affects women and is still a serious health problem in the world. ${ }^{1}$ Based on data from The Global Cancer Observatory in 2018, the number of sufferers of this cancer worldwide reached 2,088,849 (11.6\%) from a total of $18,078,957$ cancer cases. Furthermore, of the total number of sufferers of the cancer, the highest incidence was in Asia with 911,014 cases (43.6\%), where in East, Southeast, Central-South, and West Asia, the cases reached 476,509 (52.3\%), $137,514(15.1 \%), 241,077(26.5 \%)$, and 55,914 (6.1\%) respectively. In Indonesia, the most prevalent type of cancer was also breast cancer, with 58,256 cases or $16.7 \%$ of the total 348,809 cancer cases. Furthermore, in women, this type of cancer was the most common with an incidence rate of 42.1 per 100,000 population, and an average death rate of 17 per the same number of people. The second most common cancer was cervical cancer with an incidence and average death rate of 23.4 and 13.9, respectively, per 100,000 population. ${ }^{1,2}$ Data from the Hospital Information System of the dr. Saiful Anwar Malang public hospital showed that from January to December 2019, breast cancer was in the first place of the 10 types of diseases with the highest number of outpatient visits. Meanwhile, from August to December that year, the average visit of patients was 1017 per month. Currently, breast cancer treatment includes surgery, radiotherapy, chemotherapy, hormonal therapy, and biological therapy. Sixty percent of cancer patients in Indonesia that go to the hospital are those already in the advanced stage of the disease. Therefore, chemotherapy is an alternative option for treatment, in addition to radiotherapy. ${ }^{3}$ Chemotherapy is a treatment procedure where chemicals are either administered orally or through systemic infusion, with the aim of stopping or inhibiting the growth of cancer cells in the body. Furthermore, this therapy is divided into 3 types, namely, neoadjuvant, adjuvant, and palliative chemotherapy. ${ }^{4}$

Neoadjuvant chemotherapy is first given to patients before they start other treatments. The therapy is carried out to reduce cancer cells or the size of existing tumors, making it easy for them to be removed during surgery. ${ }^{5}$ The chemotherapy program that cancer patients need to undergo is not given once, as it is repeated for six treatment cycles and the interval between cycles usually lasts 2 to 3 weeks. Some patients think that the side effects of the therapy outweigh the benefits. This is because the treatment also damages healthy cells, and causes nausea, vomiting, decreased appetite, dry mouth, feeling of tiredness or weakness, hair loss, changes in the skin and nails, fever, mouth sores, impaired concentration and memory, and diarrhea in patients. Furthermore, the therapy may also cause complications such as extravasation when the drug infiltrates into the subdermal tissue at the site of intravenous access and the surrounding area. ${ }^{4}$ When patients are unable to adapt to the changes that occur in their bodies due to cancer and chemotherapy, the events become stressors and affect the bio-psycho-socio-spiritual aspects of the patient. ${ }^{6}$ In terms of psychological aspects, breast cancer patients could experience

Significance for public health

Neoadjuvant chemotherapy is the chemotherapy first given to breast cancer patients before they start other treatments. However, the medical procedure causes many complications. In a situation where patients are unable to adapt to the changes that occur in their bodies due to the medical procedure, they would be stressed and have low self-esteem. However, it was observed in this study that better family social support caused patients to have higher self-esteem. Families are the closest systems to patients that play an important role in disease management and as a coping strategy. Therefore, it was suggested that family community groups need to be developed among families that have breast cancer patients, through social networking. These groups would serve as a support system for the patients, and as a means for families to learn together and share information with fellow communities, in order to increase social support for their family members. 
changes in their self-concept, namely low self-esteem due to the decreased function of their limbs and the feeling that they cannot fulfill their role as normal individuals. ${ }^{7}$ Low self-esteem can be described as a negative feeling towards oneself, loss of self-confidence, and the feeling of worthlessness, helplessness, pessimism, and hopelessness. ${ }^{8}$ Furthermore, the condition could become chronic as the disease progresses because the incidents of being sick and treated would add to the negative perception the patients have about themselves. Patients suffering from breast cancer could express helplessness, feelings of imperfection, be ashamed of their body shape, unhappy, unattractive, less accepted by others, isolated, fear, grieve, and functional disabilities. Furthermore, they may also fail to meet family needs, experience anxiety, and hopelessness and eventually become depressed. Depressive conditions that occur in approximately $25 \%$ of cancer patients could cause more suffering and weaken the function of body organs. This would in turn disrupt treatment schedules including chemotherapy schedules. ${ }^{9}$ As explained by Wahyuni et al., ${ }^{6}$ chemotherapy involves a prolonged process, therefore, breast cancer patients need to have coping strategies and sources of support in managing the disease. Patients receiving neoadjuvant chemotherapy for the first time need a source of social support. ${ }^{6}$ Families, as the closest units to patients and have a strong influence on their development. Thus, the presence of a family would support the formation of self-identity and feelings of self-esteem for patients that are undergoing chemotherapy. ${ }^{10}$

Family social support could be manifested in the form of information, reward, emotional, and instrumental supports. Informational support is provided by the family in the form of advice for an individual, while appreciative support is provided in the form of positive expressions of respect by the family. Meanwhile, emotional support is in the form of empathy and affection provided by the family, while instrumental support is provided in the form of direct assistance. ${ }^{11}$ It is hoped that family social support would act as a means by which patients can cope when facing the illness and undergoing chemotherapy. When patients have the ability to cope with the situations effectively, they would be able to face and manage psychological problems and increase their selfesteem. ${ }^{12}$ This was confirmed by the research conducted by Zai et $a l .{ }^{13}$ regarding the relationship between family support and the level of self-esteem in stroke patients at Royal Prima Hospital Medan with 25 respondents. The research concluded that there was a relationship between family support including informational, assessment, instrumental, and emotional supports, and the level of self-esteem (self-esteem) in stroke patients. Furthermore, good family support would have a positive impact on the level of selfesteem of stroke patients. ${ }^{13}$ This study aims to ascertain the relationship between family social support and self-esteem in breast cancer patients undergoing neoadjuvant chemotherapy.

\section{Design and Methods}

This was a correlation study by design, with a cross-sectional approach, where data collection was carried out only once. It aimed to determine the relationship between family social support and self-esteem in breast cancer patients undergoing neoadjuvant chemotherapy. The population in this study were all breast cancer patients undergoing neoadjuvant chemotherapy in the X Hospital Oncology Clinic Outpatient Installation. Meanwhile, the samples were the patents out of the entire population that met the inclusion criteria, such as: i) the patient is in good general condition and can be invited to communicate, and ii) patients that are willing to become respondents in the study and signed a consent form. The sample size was 56 people, and they were selected by Simple Random Sampling. Furthermore, the independent variable was family social support, while the dependent variable was the selfesteem of the patients. The family social support questionnaire was derived from the questionnaire on respondents' perceptions of family support based on Friedman ${ }^{11}$ and Sarafino's ${ }^{14}$ theory. Furthermore, the questionnaire was tested for validity and reliability and declared valid ( $\mathrm{r}$ table value of 0.632 ) and reliable (Cronbach's-alpha value of 0.961). The self-esteem of the patients was measured using the Rosenberg Self Esteem Scale (RSES) questionnaire. Meanwhile, the data analysis methods used include first univariate analysis by describing it through tables, and then Bivariate Spearman's Rho analysis with SPSS 25 for windows.

\section{Results and Discussions}

Based on Table 1, data was obtained that almost half (33.9\%) or 19 respondents were between the ages of 41 to 50 years old. Furthermore, by education, almost half $(39.3 \%)$ or 22 of them had

Table 1. Characteristics of respondents undergoing neoadjuvant chemotherapy.

\begin{tabular}{|c|c|c|}
\hline Demographic data & n & $\%$ \\
\hline $\begin{array}{l}\text { Age (years) } \\
21-30 \\
31-40 \\
41-50 \\
51-60 \\
\text { Above } 60\end{array}$ & $\begin{array}{c}1 \\
11 \\
19 \\
16 \\
9\end{array}$ & $\begin{array}{c}1.8 \\
19.6 \\
33.9 \\
28.6 \\
16.1\end{array}$ \\
\hline $\begin{array}{l}\text { Last education } \\
\text { Elementary } \\
\text { Junior high school } \\
\text { Senior high school } \\
\text { High education } \\
\end{array}$ & $\begin{array}{c}22 \\
14 \\
12 \\
8\end{array}$ & $\begin{array}{l}39.3 \\
25.0 \\
21.4 \\
14.3\end{array}$ \\
\hline $\begin{array}{l}\text { Marital state } \\
\text { Not married } \\
\text { Married } \\
\text { Divorced (life) } \\
\text { Divorced (death) }\end{array}$ & $\begin{array}{c}2 \\
41 \\
3 \\
10\end{array}$ & $\begin{array}{c}3.6 \\
73.2 \\
5.4 \\
17.9\end{array}$ \\
\hline $\begin{array}{l}\text { Occupation } \\
\text { Business } \\
\text { Private } \\
\text { Government employees } \\
\text { Farmer } \\
\text { Retired } \\
\text { Housewife }\end{array}$ & $\begin{array}{c}4 \\
6 \\
7 \\
9 \\
3 \\
27\end{array}$ & $\begin{array}{l}7.1 \\
10.7 \\
12.5 \\
16.1 \\
5.4 \\
48.2\end{array}$ \\
\hline $\begin{array}{l}\text { Length of chemotherapy (month) } \\
\quad 1-3 \\
4-6 \\
7-9 \\
10-12\end{array}$ & $\begin{array}{c}25 \\
18 \\
6 \\
7\end{array}$ & $\begin{array}{l}44.6 \\
32.1 \\
10.7 \\
12.5\end{array}$ \\
\hline $\begin{array}{l}\text { Other diseases } \\
\text { Gastritis } \\
\text { Hypertension } \\
\text { Diabetes mellitus } \\
\text { None }\end{array}$ & $\begin{array}{c}3 \\
6 \\
1 \\
46\end{array}$ & $\begin{array}{c}5.4 \\
10.7 \\
1.8 \\
82.1\end{array}$ \\
\hline $\begin{array}{l}\text { Income/month } \\
\quad<\text { Rp 1.900.000.- } \\
\geq \text { Rp 1.900.000.- }\end{array}$ & $\begin{array}{l}35 \\
21\end{array}$ & $\begin{array}{l}62.5 \\
37.5\end{array}$ \\
\hline $\begin{array}{l}\text { Health insurance } \\
\text { Universal health coverage (BPJS Kesehatan) }\end{array}$ & 56 & 100 \\
\hline
\end{tabular}


the last elementary education. Based on marital status, most $(73.2 \%)$ or 41 respondents were married, while with respect to occupation, it was discovered that almost half (48.2\%) or 27 of them were housewives. Based on the length of chemotherapy, it was found that almost half $(44.6 \%)$ or 25 respondents had undergone chemotherapy for 1 to 3 months. Meanwhile, based on other diseases suffered by them, it was obtained that almost all $(82.1 \%)$ or 46 respondents did not suffer from other diseases besides breast cancer. Based on family income, it was obtained that most $(62.5 \%)$ or 35 respondents had an income below Rp. 1,900,000, while with respect to the financing used for the chemotherapy, all $(100 \%)$ or 56 respondents used BPJS Kesehatan for their financing. Based on Table 2, data was obtained that most of the family social support for the patients was in a good category, as this was the case reported by 36 respondents $(64.3 \%)$. Meanwhile, data was obtained that the self-esteem of almost half of the breast cancer patients $(27$ respondents or $48.2 \%$ ) was is in a moderate level category. Data analysis to test the research hypothesis was carried out using Spearman's Rho non-parametric test. Furthermore, the test used SPSS (Statistical Product and Service Solutions) version 25 and the results are presented in Table 3. This table shows that 16 respondents $(28.6 \%)$ were in the high self-esteem category, while $20(35.7 \%)$ were in the moderate category. The significance value was $p=0.000$, which was less than 0.05 , while the calculated $r$ value was 0.762 . This means that there was a strong and positive correlation between the two variables, namely family social support, and patient self-esteem. Consequently, it can be stated that when the social support provided by the family was better, the patients had a higher level of self-esteem. This study obtained that the family social support of most of the patients was in a good category, (36 respondents or 64.3\%). According to Friedman et al., ${ }^{11}$ family support is the attitude, action, and acceptance of the family to provide support and assistance in the form of informational support (advice, advice, information), appreciation support (respect, feedback), emotional support (attention, compassion, empathy), and instrumental support (assistance of energy, funds, and time) for

Table 2. Family social support and self-esteem.

\begin{tabular}{lcc} 
Variables & n & $\%$ \\
Family social support & & \\
$\quad$ Good & 36 & 64.3 \\
Average & 11 & 19.6 \\
Less & 9 & 16.1 \\
Self-esteem & & \\
High & 16 & 28.6 \\
Middle & 27 & 48.2 \\
Low & 13 & 23.2 \\
\hline
\end{tabular}

its member. ${ }^{11}$ Based on this research, the respondents were breast cancer patients, thus, it would be very appropriate when most of the social support provided by the family to the respondents is in the good category. Breast cancer is a malignant disease that rises from breast tissue due to the irregular and chronic division of body cells. ${ }^{15}$ Based on this research, breast cancer patients that are at the beginning of their neoadjuvant chemotherapy treatment really need social support from their families because this can motivate them to undergo more chemotherapy sessions and make them comply with the chemotherapy drug regimen recommended by the doctor. When social support is provided by families, patients feel that someone still gives attention, affection, or cares for them even though they are suffering. Family is a patient's closest environment where mutual interaction between individuals occurs. The importance of family social support for cancer patients undergoing chemotherapy was reinforced by the research of Roza and Setiawati on 120 cancer patients undergoing chemotherapy at Dr. H. Abdul Moeloek. The research showed that family support had a significant correlation with the breast cancer patients undergoing chemotherapy. ${ }^{16}$ When family support is high, the value of patient compliance to the chemotherapy regimen would be high. Conversely, when the value of family support is low, the value of compliance would also be low.

Patient adherence in undergoing chemotherapy cannot be separated from the information support provided by the family. From the results, it was observed that almost half of the respondents, 22 of them, had primary school education $(39.3 \%)$, while 14 had the latest junior high education (25\%). According to the theory by Friedman et al., ${ }^{11}$ the family functions as a collector and disseminator (spreader) of information, and, to provide support, they also carry out socialization function. ${ }^{11}$ According to Padila, the stages of individual and family development would be achieved through interactions or relationships embodied in socialization. ${ }^{17}$

Socialization which occurs due to social interaction and a good learning process would cause changes in the knowledge, attitudes, and behavior of family members. Information support for cancer patients undergoing neoadjuvant chemotherapy can be in the form of educating the patients about the side effects of chemotherapy, providing advice on the need to eat nutritious foods to support good health, always reminding them to adhere to the chemotherapy schedule, and finally, always providing information related to the patient's disease any time they need it. However, families cannot provide all this information on their own, thus they need more knowledge from other family members as informants, or where necessary, they can refer to accurate information from social media. With the transfer of information, the patient's knowledge increases, therefore, this can be a coping strategy for patients against their anxiety, when dealing with the disease and undergoing the initial period of treatment.

Table 3. The relationship between family social support and self-esteem.

\begin{tabular}{llccccc} 
Cross tabulation & & Self-esteem & & Amount & P-value & r-count \\
Family social support & Good & 16 & 20 & 0 & 36 & 0.000 \\
& & $(28.6 \%)$ & $(35.7 \%)$ & $0 \%$ & $(64.3 \%)$ & 0.762 \\
& Average & 0 & 7 & 4 & 11 & $(19.6 \%)$ \\
& & $0 \%$ & $(12.5 \%)$ & $(7.1 \%)$ & 9 & $(16.1 \%)$ \\
\hline
\end{tabular}


Judging from the age of the respondents, almost half of them (19 or $33.9 \%$ ) were within the ages of 41 to 50 years old, 16 respondents $(28.6 \%)$ were aged 51 to 60 years, while a small proportion of 9 respondents $(16.1 \%)$ were aged more than 60 years. According to Ratna, ${ }^{18}$ in terms of recipients of social support, attention needs to be given to the characteristics of assistance, personality, and social roles of the recipients of the support. Based on this research, the age of someone that receives social support also needs to be considered. This is because as people get older, they experience many changes in the body, which would cause limitations and physical setbacks. Also, in the case of the elderly, they may experience a lot of cognitive decline. This was confirmed by Azizah $^{19}$ that health problems often occur in the elderly, and an example is a decrease in cognitive function. The decline in cognitive function is usually marked by decreasing memory and understanding, and reduction in perception, reasoning, language fluency, and ability to solve problems. Therefore, when elderly people have chronic breast cancer, they need more intense social support from their families. ${ }^{19}$

One of the factors that influence family social support is family practice. ${ }^{20}$ Family practice shows the role of the family in supporting the health care efforts of each of its members. For example, a patient would carry out every precautionary measure when it is supported by the family. According to research, family practice is inseparable from the existence of family functions that are carried out. When the family's social support is good, then the family has carried out its function properly.

In this study, in addition to the socialization function, the family functions that could have played a role in providing social support for the breast cancer patients include affective, economic, and health care functions. Harmoko ${ }^{21}$ stated that affective function has components of mutual care, love, warmth, mutual acceptance, mutual respect, bonding, or affection. According to research, affective function can be seen when a family member has cancer because, in such a situation, the families cannot escape their involvement in providing social support in dealing with the suffering of the sick family member. This is in accordance with Harmoko's theory ${ }^{21}$ which stated that there is an identification process in carrying out family functions, in which one family member experiences what happens to other family members. In line with the implemented family affective function, family social support in the form of emotional support, motivation, and encouragement is highly expected by patients when undergoing chemotherapy treatment. According to Friedman et al., ${ }^{11}$ the family functions as a port of rest, recovery and helps in controlling the patient's emotions. Furthermore, based on this study, the emotional support provided by the family can make individuals feel that they are not bearing their own burdens. This is because there is warmth from the caring family, affection, enthusiasm, willingness to hear all the complaints and problems at hand, and even to help solve the problems. ${ }^{11}$ This was confirmed by Ratna ${ }^{18}$ that emotional attention can be expressed through love and affection or supportive empathy. By showing a smiling expression one can give a sense of peace to another. According to research, someone suffering from chronic breast cancer usually has their own opinion about the disease they suffer, namely blaming themselves, since they often think they are the cause of the disease due to their bad behavior such as eating unhealthy food or a hereditary disease that could not be cured. It makes them resign to face the situation.

Social support cannot be separated from the role of the family in building the self-esteem of breast cancer patients. This is because patients get appreciation or recognition from the family despite their chronic illness. By maintaining a positive climate where each family member is recognized and respected for their existence and rights, the affective function would be achieved. ${ }^{22}$ One of the factors that influence the effectiveness of social support is social support itself, and in this case, it is provided by the family. Individuals would not get support when the provider does not have the various resources needed. For example when the support provider is in a state of stress or is in need of help or not sensitive enough to the needs of others. ${ }^{23}$ According to research, inadequate family income can be the reason for the lack of social support. In this case, the economic function in the family is not going well. The economic condition of the family is related to the instrumental support provided such as services, financial assistance, materials in the form of real assistance, where the objects or services provided would help solve problems. Instrumental support can be provided directly by the family and includes material assistance such as providing settlement, lending or giving money, providing transportation, looking after and caring for family members that are sick and providing equipment and medicines needed. This was emphasized by Harmoko, ${ }^{21}$ that the economy is an element that supports family independence and resilience and helps family members meet their needs. This was further reinforced by Sari's research ${ }^{20}$ that economic stability causes an individual to be more responsive to every symptom of the disease that arises. This means that individuals would immediately seek help when their health is disturbed. Even though there are obstacles such as poor family economic conditions, the family's social support would be more optimal with the existence of health insurance from the government in the form of BPJS Kesehatan to finance chemotherapy. ${ }^{18}$ From the results of the study, it was found that all research respondents (56 people or $100 \%$ ) used BPJS Kesehatan to pay for chemotherapy.

Another factor that influences the effectiveness of social support is the recipients of the social support. ${ }^{24}$ The instrumental support provided can help individuals carry out their activities, such as doing daily household tasks, therefore, preventing the sufferers from being fatigue. ${ }^{25}$ Based on the results of this study, it was found that almost all the respondents were housewives, namely 27 people (48.2\%). Furthermore, of the 27 housewives, most had good socio-family support (19 people or $70.4 \%$ ). According to research, housewives are women that are married and do not work, instead, they spend part of their time taking care of the household. It is not every day these women find the same atmosphere and routine tasks and carry out the responsibility of taking care of the needs at home. In this case family social support is matched with the characteristics of the recipient of support. Based on the description above, it is concluded that in providing social support for breast cancer patients that undergo neoadjuvant chemotherapy, the patients themselves need to be considered, as that is the only way the support could be effective. The recipients of the support can be influenced by age, education level, and occupation. With regards to the providers of the support, which in this case is the family, they are influenced by family practices. Family practices that are carried out with good family functions and are aware of family health duties such as recognizing the family health problems, making appropriate health action decisions, providing care for sick members, and maintaining a healthy home atmosphere, would create good social support. From the results of this study, it was found that respondents that had moderate self-esteem were more than those with high and low self-esteem. This is due to the patients' perception of their physical condition of suffering from breast cancer. Breast cancer is a chronic disease and is complex in its treatment, unlike colds and mild illness, that only require medication to cure their symptoms. Breast cancer patients tend to have negative ways of thinking, therefore, the incidence of the illness and the condition of being treated with chemotherapy would add to their negative or deficient perceptions. In this study, the negative think- 
ing of the patients was also due to the disorders they experienced in their body image. This condition was experienced by almost all respondents, as 47 of them (83\%) suffered hair loss and baldness, their bodies became thin, and they suffered other side effects. By experiencing these many limitations and weaknesses, the patients felt worthless and unable to carry out the normal activities of physically normal people. According to research, self-esteem is one of the basic human needs that need to be met to achieve self-actualization. Meanwhile, self-actualization could give an individual the feeling of being successful and useful, even when that individual is actually weak and experienced failure.

The second factor that can affect a person's self-esteem is the physical condition of undergoing chemotherapy regularly every 21 days. The physical condition of an individual that has to undergo chemotherapy due to cancer would not be optimal because this condition makes a person feel like they have limitations, are unable to carry out activities as usual, and experience weakness in their limbs. Furthermore, these physical changes would affect the selfesteem of the patients. From the results of the study on the length of undergoing chemotherapy, almost half of the respondents had been undergoing the therapy for 1-3 months (25 respondents or $44.6 \%$ ), while 28 respondents $(32.1 \%)$ had been undergoing the procedure for 4-6 months. In the early days of undergoing neoadjuvant chemotherapy, breast cancer patients would experience the effects of the therapy, which could or could not be tolerated, depending on the patient. However, when patients cannot tolerate the effects, they become potential stressors to such individuals. The increasing stress can trigger a psychological response that may be adaptive in the individual. However, when the response is not adaptive, it would cause a change in the self-esteem of the patients. Psychological conditions related to self-esteem in breast cancer patients undergoing neoadjuvant chemotherapy may decrease along with the presence of other comorbidities. In this study, for instance, 10 respondents $(17.9 \%)$ stated that they suffered from other illnesses. They include 3 respondents $(5.4 \%)$ that had gastritis, $6(10.7 \%)$ that suffered from hypertension, and $1(1.8 \%)$ that had diabetes mellitus. Of the 10 respondents, it was observed 4 of them $(40 \%)$ had low self-esteem. This was confirmed in the results of Coopersmith's research in Ghufron and Risnawita, ${ }^{22}$ which revealed that there is a strong influence between visible appearance and self-esteem, where the satisfaction that occurs due to good physical condition would build high self-esteem. The third factor that could affect a patients' self-esteem is their social and economic status. ${ }^{18}$ In this study, identifiable social and economic status includes recent education, marital status, occupation, and family income or personal income. Based on the latest education, almost half of the respondents had elementary school education (22 of them or $39.3 \%$ ). Furthermore, of these 22 people, 13 $(59.1 \%)$ had moderate self-esteem while $6(27.3 \%)$ had low selfesteem. The results of this study are in line with research conducted by Sudana et $a l .{ }^{23}$ regarding the description of the self-esteem of breast cancer patients undergoing chemotherapy. The research showed that the majority of respondents with high school and university education had high self-esteem, while the majority that had elementary education had moderate self-esteem. Therefore, it can be concluded that a person's self-esteem could be affected by the level of education. Also, the higher a person's level of education, the better the level of self-esteem of that individual.

A person's education indirectly affects the ability to adapt to stressors and success. Individuals with high self-esteem would achieve their life goals more enthusiastically than those with low self-esteem because when an individual has high self-esteem that person would have better intelligence scores and always try hard. ${ }^{24}$ Formal education essentially functions as a means of empowering individuals to increase knowledge in the context of developing self-potential. The higher a person's education, the faster that person will absorb knowledge, which would then increase the person's self-esteem. Meanwhile, this increase in self-esteem would boost the person's confidence when interacting with other people. ${ }^{25}$ This research suggests that respondents that have higher education and knowledge would always develop insight and be updated about disease management. Social status can be viewed from marital status. Based on marital status, most of the respondents were married (41 of them or $73.2 \%$ ). Furthermore, of the 41 married people, 9 (22\%) had high self-esteem, while 21 (51.2\%) had moderate self-esteem. According to Hidayati and Sutini, ${ }^{25}$ selfesteem is obtained when a person feels loved by a spouse, respected, valued and praised. When compassion and love no longer exist, respect and mutual respect would be lost. According to research, in a household, a husband that always accompanies a wife suffering from breast cancer undergoes tests in life, such as having a difficult time accompanying the wife when undergoing cancer treatment. However, when a husband accompanies the wife during treatment, helps out at home, and is always attentive and responsive to all the complaints made regarding the illness, it would foster a feeling of affection and love between the partners. Furthermore, in such a situation, the wife would feel cared for, respected, and needed, therefore, there would be an increase in thy self-esteem. Increase in the self-esteem of individuals causes them to accept themselves, and this would further increase the their positive feelings, regardless of the changes in the appearance of their body. ${ }^{25}$ This was confirmed by the qualitative research conducted by Aulia, ${ }^{26}$ which showed that good support from husbands for wives with cervical cancer undergoing chemotherapy had a positive effect on the quality of life of the wives in terms of their physical and psychological health. However, there are some types of good support from husbands that do not affect the quality of life of their wives in terms of physical health, but psychologically they still have a good effect. $^{26}$

The next social and economic status factor that could affect self-esteem is one's job. ${ }^{18}$ In this study, it was observed that almost half of the respondents, namely 27 people (48.2\%) were housewives. Furthermore, of the housewives, most (14 or 51.9\%) had moderate self-esteem, while $8(29.6 \%)$ had high self-esteem. According to Morris Rosenberg's theory, self-esteem consists of 2 aspects, namely esteem and ability. ${ }^{27}$ The first aspect of selfesteem is esteem, and it has to do with a person seeing oneself as someone of value and worth. Individuals that have feelings of worth would judge themselves positively and feel confident. The second aspect of self-esteem is ability, and it involves a person seeing oneself as someone that has the ability and means to achieve an expected result. When people succeed in achieving set out goals, they would give a positive assessment of themself, and feel confident. According to research, socially, housewives do not work, feel less productive, are less able to develop themselves, and depend on their husbands/families for their financial needs. Therefore, it is likely that housewives are affected by feelings of inferiority and helplessness, which decreases their self-esteem when compared to someone that has a high position and social class, for example a civil servant or an entrepreneur. Housewives, that have a good relationship with the family and the surrounding environment and are wholly accepted contribute to the family. Even though they suffer from breast cancer, they would still be able to manage the household and take care of their families. This can cause a woman to be more confident and prouder to be a housewife, to feel capable, motivated, and enthusiastic, regardless of the changes in thy body. In the end, such a woman would feel needed by the family and the surrounding environment and thus be able to accept the ill- 
ness and respect herself. Based on the description above, it was concluded that it is important to understand the self-esteem of breast cancer patients, which can be seen from gender, physical condition, and social and economic status. Self-esteem is closely related to the happiness, psychological resilience, and motivation of breast cancer patients to undergo chemotherapy treatment and make life more productive despite their health problems.

Family social support is very useful for building self-esteem in patients. When the family's social support is good, self-esteem would also high. Conversely, when the family's social support is low, self-esteem would also be low. This is in accordance with the theory put forward by Ratna ${ }^{18}$ that family social support is an important factor that someone needs when facing health problems, as a preventive strategy to reduce stress, increase the view of life, and as an important coping strategy. Social support is the existence of other people that are trusted, reliable, give attention, and can make a person feel that they exist and are valued. Therefore, unfavorable family circumstances would complicate a patients' healing process. ${ }^{18}$ According to research, good social support from families in the form of informational, rewarding, emotional, and instrumental support could directly provide physical and psychological comfort to sick family members. Therefore, in the case of breast cancer patients, they would feel respected, needed, and cared for by their family. This study was in line with the research conducted by Wibowo, ${ }^{28}$ which stated that there was a significant relationship between family support and the self-esteem of chronic kidney failure patients undergoing hemodialysis at Dr. Kanujoso Djatiwibowo Balikpapan, with a p-value of 0.040. In that research, it was observed that the higher the family support, the higher the self-esteem of the patients. ${ }^{28}$ Another study which was in line with this study is the research by Zai et al. ${ }^{13}$ regarding the relationship between family support and the level of self-esteem in stroke patients at Royal Prima Hospital Medan with 25 respondents. In that research, it was concluded that there was a relationship between family support namely informational, assessment, instrumental, and emotional support, and the level of self-esteem (selfesteem) of CVA patients. Furthermore, it was concluded that good family support would have a positive impact on the level of selfesteem in the patients. ${ }^{13}$

\section{Conclusions}

Family social support for breast cancer patients undergoing neoadjuvant chemotherapy at the Oncology Clinic Outpatient Installation of X Hospital was in a good category because 36 respondents $(64.3 \%)$ were in the category. Furthermore, the selfesteem of the patients was in the moderate level category because 27 respondents $(48.2 \%)$ were in the category. There was a strong positive correlation between family social support and the selfesteem of the patients, thus, a better family's social support correlated with higher self-esteem in patients.
Correspondence: Sih Ageng Lumadi, Nursing Study Program, Maharani Health College, Jl. Akordion Selatan 8B, 65141 Malang, Indonesia.

Tel. +62.3414345375 - Fax: +62.3414345375 .

E-mail: lumadi@stikesmaharani.ac.id

Key words: Family social support; self-esteem; breast cancer patients; neoadjuvant chemotherapy.

Acknowledgments: The authors re grateful to the Maharani Health College and dr. Saiful Anwar Public Hospital, Malang, Indonesia for their kind support and encouragement during this study.

Contributions: All authors contributed equally to this article. EA conducted the study; FI and SAL served as supervisors and reviewed the final article.

Conflict of interests: The author declares that there was no potential conflict of interest.

Funding: This study was financially supported by the Maharani Health College, Malang, Indonesia.

Ethics approval: The study protocol was approved by the Research Ethics Committee of the dr. Saiful Anwar Public Hospital $(400 / 136 / K .3 / 302 / 2020)$. Furthermore, offline informed consent was obtained from the participants, and participation was anonymous.

Conference presentation: Part of this study was presented at the $1^{\text {st }}$ International Nursing and Health Sciences Symposium, November $13^{\text {th }}$ to $15^{\text {th }} 2020$, Brawijaya University, Malang, Indonesia.

Received for publication: 14 January 2021.

Accepted for publication: 20 March 2021.

o Copyright: the Author(s), 2021

Licensee PAGEPress, Italy

Journal of Public Health Research 2021;10:2234

doi:10.4081/jphr.2021.2234

\section{References}

1. Rasjidi I. [Epidemiologi Kanker pada Wanita (Epidemiology of Cancer in Women)].[Book in Indonesian]. Jakarta: CV Sagung Seto; 2010.

2. World Health Organization. Breast cancer fact sheet. Geneva: WHO; 2018.

3. Setiati S. [Buku Ajar Ilmu penyakit Dalam Edisi Keenam Jilid III (Textbook of Medicine, Vol. 3, 6th ed)].[Book in Indonesian]. Jakarta Pusat: Interna Publishing; 2014.

4. Firmana D. [Keperawatan Kemoterapi (Chemotherapy nursing)].[Book in Indonesian]. Jakarta: Salemba Medika; 2017.

5. Etika NM. Kemoterapi: Bisa Menyembuhkan, Bisa Juga Mematikan (Chemotherapy: It can be curing, it can also be deadly)].[in Indonesian]. 2020 [updated 2020 Sept; cited 2020 Nov]. Available from: https://hellosehat.com/hidup-sehat/tipssehat/efek-kemoterapi-pengobatan-kanker/

6. Wahyuni D, Huda N, Utami GT. [Pengalaman Pasien Kanker Stadium Lanjut Yang Menjalani Kemoterapi (Experience of advanced stage cancer patients undergoing chemotherapy)].[Article in Indonesian]. J Online Mhs 2016;2: 1048-57.

7. Potter P, Perry AG. [Fundamental Keperawatan, Edisi 7, Buku 1 (Nursing fundamentals, Issue 7, Book 1)].[Book in Indonesian]. Jakarta: Salemba Medika; 2010. 
8. Azizah LM, Zainuri I, Akbar A. [Buku Ajar Keperawatan Kesehatan Jiwa: Teori dan Aplikasi Praktik Klinik (Textbook of mental health nursing: Theory and application of clinical practice)].[Book in Indonesian].Yogyakarta: Indomedia Pustaka; 2016.

9. Diananda R dr. Mengenal Seluk-Beluk Kanker (Know the ins and outs of cancer)].[Book in Indonesian]. Jogjakarta: Katahati; 2010.

10. Andarmoyo S. [Keperawatan Keluarga: Konsep Teori, Proses dan Praktik Keperawatan (Family nursing: Concepts of nursing theory, process and practice)].[Book in Indonesian]. Yogyakarta: Graha Ilmu; 2012.

11. Friedman M, Bowden O, Jones M. [Buku Ajar Keperawatan Keluarga: Riset, Teori, \& Praktik (Textbook of family nursing: Research, theory, and practice)].[Book in Indonesian]. 5th ed. Jakarta: EGC; 2010.

12. Makisake J, Rompas S, Kundre R. [Hubungan Dukungan Keluarga Dengan Harga Diri Pasien Kanker Payudara Yang Menjalani Kemoterapi (The relationship between family support and the self-esteem of breast cancer patients undergoing chemotherapy)].[Article in Indonesian]. e-Journal Keperawatan 2018;6:1-6.

13. Zai Y, Bu'ulolo K, Fajariani N, et al. Hubungan Dukungan Keluarga Dengan Tingkat Self Esteem (Harga Diri) Pada Penderita Stroke Di Rumah Sakit Umum Royal Prima Medan 2019 (Relationship between family support and self esteem levels in stroke patients at the Royal Prima Medan General Hospital 2019)].[Article in Indonesian]. J Ris Hesti Medan Akper Kesdam I/BB Medan 2019;4:66.

14. Sarafino EP. Health Psychology biopsychososial interactions. New York: J. Wiley \& Sons, Inc.; 2011.

15. Wijaya AS, Yessie MP. KMB 2: Keperawatan Medikal Bedah - Keperawatan Dewasa Teori dan Contoh Askep (MB 2: Medical surgical nursing - Adult nursing theory and examples of askep)].[Book in Indonesian]. Yogyakarta: Nuha Medika; 2015.

16. Roza GE, Setiawati OR. [Hubungan Dukungan Keluarga Dengan Kepatuhan Pasien Kanker Payudara Menjalani Kemoterapi (The relationship between family support and compliance with breast cancer patients underwent chemotherapy)].[Article in Indonesian]. J Psychol 2019;2:159-68.

17. Padila. [Buku Ajar: Keperawatan Keluarga (Textbook: Family nursing)].[Book in Indonesian].Yogyakarta: Nuha Medika; 2012.

18. Ratna W. [Sosiologi Dan Antropologi Kesehatan/Keperawatan Beserta Aplikasinya (Sociology and anthropology of health/Nursing and their applications)].[Book in Indonesian]. Yogyakarta: Pustaka Rihama; 2010.
19. Azizah LM. [Keperawatan Lanjut Usia (Elderly nursing)].[Book in Indonesian]. Yogyakarta: Graha Ilmu; 2011.

20. Sari DAKW. (Analisis Faktor Yang Berhubungan Dengan Harga Diri Pasien Kusta Di Rumah Sakit Kusta Kediri (Analysis of factors related to leprosy patient self-esteem at the Kediri leprosy hospital)].[in Indonesian]. Malang, Brawijaya University Nursing Master Program; 2017.

21. Harmoko. [Asuhan Keperawatan Keluarga (Family nursing care)].[Book in Indonesian]. Yogyakarta: Pustaka Pelajar; 2012.

22. Ghufron MN, Risnawita R. [Teori-Teori Psikologi (Psychological theories)].[Book in Indonesian] Yogyakarta: Ar- Ruzz Media; 2010.

23. Sudana IK, Chrisnawati, Maratning A. [Gambaran Harga Diri Pada Pasien Kanker Payudara Yang Menjalani Kemotrapi Di RSUD Ulin Banjarmasin Tahun 2014 (Description of selfesteem in breast cancer patients undergoing chemotherapy at Ulin Hospital, Banjarmasin in 2014)].[Article in Indonesian]. Jurnal Keperawatan Suaka Insan (JKSI) 2016;1:44-9.

24. Ghufron. Teori-Teori Perkembangan (Theories of development)].[Book in Indonesian]. Bandung: Refika Aditama; 2010.

25. Hidayati NO, Sutini T. [Gambaran Harga Diri Warga Binaan Perempuan Di Lembaga Pemasyarakatan X Bandung (Image of self-esteem of women assisted by prisoners in Bandung Penitentiary X)].[Article in Indonesian]. J Keperawatan BSI 2017;5:1-7.

26. Aulia N. [Dukungan peran Suami Dalam peningkatan Kualitas hidup Pada pasien Kanker Serviks Akibat kemoterapi di ruang Edelweis RSUD Ulin Banjarmasin (Support for the husband's role in improving the quality of life of cervical cancer patients due to chemotherapy in the Edelweiss room at Ulin Hospital, Banjarmasin)].[in Indonesian].Banjarmasin: Universitas Sari Mulia; 2017.

27. Riadi M. [Pengertian, Aspek, Komponen dan Faktor yang Mempengaruhi Harga Diri (Definition, aspects, components and factors affecting self-esteem)].[in Indonesian]. KajianPustaka.com [Internet]. 2017 Available from: https:/www.kajianpustaka.com/2017/12/pengertian-aspekkomponen-dan-faktor-yang-mempengaruhi-harga-diri.html

28. Wibowo TA. [Hubungan Antara Dukungan Keluarga Dengan Harga Diri Pasien gagal Ginjal Kronik yang Menjalani Hemodialisis di RSUD Dr. Kanujoso Djatiwibowo Balikpapan (The relationship between family support and self-esteem in chronic kidney failure patients undergoing hemodialysis)].[Article in Indonesian]. J Ilmu Kesehat 2017;5:56-60. 